For citing: Tillmanns M. How doing Philosophy with Children enhances Proprioception of Thinking and Emotional Intelligence // Socium i vlast'. 2020. № 1 (81). P. 90-95. DOI: 10.22394/1996-0522-2020-1-90-95.

DOI: 10.22394/1996-0522-2020-1-90-95

UDC $101.8+101.9$

\section{HOW DOING PHILOSOPHY WITH CHILDREN ENHANCES PROPRIOCEPTION OF THINKING AND EMOTIONAL INTELLIGENCE}

Tillmanns Maria daVenza,

University of California, San Diego, USA, PhD, UC San Diego 9500 Gilman Dr. La Jolla, CA 92093 E-mail: davenza@sbcglobal.net

Abstract

The article is a more detailed consideration of the problems that were outlined in the first part of this

study, "The Application of the Proprioception of Thinking in Doing Philosophy with Children" (Socium and Power, 2019, no. 4). This time, the author pays attention to the characterization of thinking as a process in the practice of philosophizing with children, justifying the effectiveness of this practice, which forms the awareness of actions and develops emotional intelligence. The author contrasts static abstract thinking with the dynamics of a tacit

concrete process of thought. Philosophizing with children in a dialogue form completely engages in the thought process, focuses on the very thinking, which is constantly developing taking into account different points of view, is complicated and deepens the understanding on an emotional level.

Key concepts: philosophy with children proprioception sensual and rational, abstract thinking vs. implicit concrete thought process, emotional intelligence.

\section{Introduction}

Philosophy with children often focuses on abstract reasoning skills, but as David Bohm points out the "entire process of mind" consists of our abstract thought as well as our "tacit, concrete process of thought." Philosophy with children should address the "entire process of mind." Our tacit, concrete process of thought refers to the process of thought that involves our actions such as the process of thought that goes into riding a bicycle. Bohm contends that we need to develop an awareness or proprioception of thinking as well.

When Socrates enters into dialogue with his interlocutors, he equally shows the limitations of purely abstract thought by leading them to admit that they really "don't know." But, of course, they know. We know what bravery is or what love is, even though we can never "explain" these concepts in abstract terms. Life has taught us through experience what these concepts mean and we have developed an understanding of them. We can recognize when a person acts bravely.

This is where I see the link between our tacit, concrete process of thought and emotional intelligence. We need emotional intelligence to learn how to be brave, to learn how to love, and be just in the way we act in the world. Knowing what justice is abstractly does not make us act justly.

We have to develop awareness of our actions in order to develop the skills necessary to act the part. This is also where emotional intelligence comes in. In the bulletin of the play Romeo and Juliet, director Barry Edelstein wrote the following: "To perform Romeo and Juliet, actors need a series of skills... they must have the emotional and psychological awareness and openness of uncommon depth; they must listen with acuteness, they must possess an imagination of real suppleness and subtlety..." [5] An abstract portrayal would not bring these characters to life.

We can surely agree - abstractly - that racism is destructive, but still act racist, without being even slightly aware of it. So how do we become aware? In The New York Times article "The Big Business of Unconscious Bias," Nora Zelevansky addresses how traditional sensitivity training can not only be ineffectual but also breed resentment [9]. My contention is that while our abstract sense of racism has evolved, our tacit, concrete knowledge has not, which explains that racism is for the most part still rampant, even though we know abstractly that it is wrong.

So how do we educate and develop the awareness of the tacit, concrete knowledge that informs our actions, and develop the emotional intelligence to give a depth of understanding to what we know and believe abstractly. 


\section{Proprioception of Thinking}

In On Dialogue, David Bohm makes the case that while proprioception is generally associated with body movement and the self-perception of body movement, it can also be made to apply to the "movement" of thinking: "Proprioception" is a technical term - you could also say "self-perception of thought," "self-awareness of thought," or "thought is aware of itself in action." Whatever terms we use, I am saying: thought should be able to perceive its own movement, be aware of its own movement. In the process of thought there should be the awareness of that movement, of the intention to think, and of the result which the thinking produces" [1, p. 79].

Proprioception refers to the physical knowledge acquired in the process of doing a particular activity, such as riding a bicycle. Likewise, Bohm suggests, we can become aware of our thinking in the process of thinking. For Bohm, to see the process of thinking as a "movement," of which we can become aware, opens the door to an understanding of thinking as a process we do with "our entire being." We are after all, thinking beings. And while we may not be aware of it, thinking also informs our emotions and actions on a tacit, concrete level. Is the thinking we do abstractly consistent, or as Bohm would say, "coherent" with the thinking that takes place on the tacit, concrete level of thought that informs our emotions and actions?

Imposing the abstract knowledge of knowing what it is to be brave does not enable one to be so. The question is: do we have the emotional depth of understanding to act bravely as well? Socrates makes this point as well indicating that philosophy is the art of understanding the nature of something, the nature of what it means to be courageous in Laches, or the nature of friendship in Lysis, with the notion that along with this deeper understanding you are able to act on what it means to be courageous or what it means to be a friend. He makes a clear distinction between knowledge and understanding. He understands the limitations of abstract knowledge and in that way knows that he does not know. In the Symposium he brings in Diotima who, at the hand of a myth, provides us an understanding of love, after everyone else has tried to define love abstractly [7].

Understanding does not have these limitations. The "openness of uncommon depth" at which we can understand something is endless. It is in constant movement and with every breath can become deeper and fuller. But how do we teach for this kind of "emotional and psychological awareness and openness of uncommon depth," so we can enact what we believe abstractly.

\section{Developing Understanding through Proprioception}

In other words, developing an understanding of what it means to act bravely has to take place in the tacit, concrete process of thought, which guides our actions. "This tacit, concrete process is actual knowledge... In the case of riding a bicycle, if you don't know how to ride, then the knowledge isn't right - the tacit knowledge is not coherent in the context of trying to ride the bike, and you don't have the intended result. The incoherence becomes clear - you fall when you want to ride. Physically, tacit knowledge is where the action is coming from. And physical change depends on changing the tacit response. Therefore, changing the abstract thought is one step, but unless it also changes the way the body responds, it won't be enough... You need the tacit knowledge which you get by actually riding ..." [1, p. 78-79] Tacit knowledge of racism, for example, has to be "coherent" in the context of knowing racism abstractly. To tell people not to be racist without teaching them how not to act racist changes little if anything.

Making children aware of themselves as thinking beings at a young age, when they are still predominantly operating from a tacit, concrete knowledge basis as opposed to one driven by abstract knowledge, is why doing philosophy with children is so crucial. Doing philosophy with children engages them as thinking beings and not solely as abstract (critical) thinkers. We engage children in the process of thinking.

Dr. Maria Montessori developed a method of teaching based on providing young children with concrete experiences of the teaching tools she devised from which they could then better understand abstract concepts. For example, some of her teaching tools give children sensory experiences of the alphabet, having children trace a letter ' $a$,' for example, made of sandpaper with their fingers while pronouncing the letter. She also created small bars of glass beads so children could feel the beads while counting them out loud. Essentially, she developed teaching tools, which served to educate the concrete, tacit process of thinking before introducing abstract concepts. In this way, children are actively engaged and emotionally engaged in the process of learning. In doing philosophy with children, children who think with their "entire being" are also actively engaged in the process of thinking, as a process.

\section{The Importance \\ of Doing Philosophy with Children}

Philosophy with children dialogues engages children as whole beings. Children's opinions are 
not solely abstract opinions; they are lived opinions. In the process, they experience that they matter; their thoughts and feelings are taken seriously, and as a result they learn to take themselves and their own thoughts and feelings seriously as well - they learn that they matter to themselves as well.

In our philosophy discussion groups, I always give children what I call "thinking time," and allow the children to ponder how to articulate what they feel and think into words. They need to use their complete mind, not just their abstract mind. Thinking with one's whole being takes time and children learn the importance of respecting that time. Teachers I have worked with have also commented on the fact that they appreciate how I give children enough time, without fear of losing control of the group discussion. When they have "thought things through," they are ready to talk and share their ideas with the group. If they need more time, I come back to them later or may even ask a friend to help them out, because sometimes, the friend can offer ideas that help the child formulate what they want to say.

It is interesting to note that some children who otherwise rarely speak up in class feel comfortable doing so in our philosophical discussion groups. Focusing on thinking as a movement creates a space for thinking to accommodate, to listen to other points of view and to integrate these into one's own thinking as it evolves, while trying to develop a deeper understanding of the complexity involved. Children readily change their minds, when they hear someone else's opinion that makes more sense to them. Thinking as a movement accommodates other points of view similar to how our eyes accommodate and adjust the optics of the eye to keep an object in focus. Doing philosophy with children focuses on thinking that is constantly evolving with the input of other points of view, as thinking that increases in complexity and emotional depth of understanding.

\section{Emotional Intelligence and "Suspension" of Thought}

"Emotional life grows out of the brain called the limbic system, specifically the amygdale. The amygdala processes fear and anger, delight and disgust. It reacts to immediate impulses. Much later the neocortex was added which processes longer-term interests, enabling us to learn, plan and remember. The more connections between both the limbic system and the neocortex, the more emotional responses are possible" (emphasis added) [3].

The article goes on to say that, "if there is a cornerstone to emotional intelligence on which most other emotional skills depend, it is the sense of self-awareness.... Once an emotional response comes into awareness - or physiologically, is processed through the neocortex the chances of handling it appropriately improve. Scientists refer to "metamood," the ability to pull back and recognize that "what I am feeling is anger," or sorrow, or shame" (emphasis added) [3, p. 63]. For clarification, "metamood" is distinctly different from the idea of "meta-cognition," in that the former refers to one's ability to "pull back" in the moment.

While scientists talk about the "ability to pull back," David Bohm talks about the need for "suspension." "The human race doesn't do a great deal of suspension of this sort... Our development has been more toward a kind of immediate impulsive response..." [1, p. 74] Bohm goes on to say: "Is it possible for thought to similarly observe itself, and see what it is doing, perhaps by awakening some other sense of what thought is, possibly through attention? In that way, thought may become proprioceptive. It will know what it is doing and will not create a mess... And clearly, when thought does not know what it is doing, then such a mess arises. So let us look further - first at suspension, then at proprioception" [1, p. 75-76].

Both Bohm's notion of developing one's ability for "suspension" and the skill to develop "metamood" create the self-awareness necessary to exercise greater self-control, without suppressing the feelings so necessary for increased understanding of the world we participate in. In HR Matters Magazine, Linda Elders has an article, "Becoming a Critic of Your Own Thinking". In her article she states, that "a popular way of conceptualizing the mind is to separate thinking from emotions." But this conceptualization, she argues, is just not true, that we need to be very aware of both our emotions and our thoughts and how, more importantly, they interrelate. Critical thinkers take command of their emotions. They grasp the root of their own thought and emotion [2, p. 4-5].

\section{Emotional Intelligence and Developing Deeper Understanding}

And as noted earlier, the more connections between the limbic system and the neocortex, the more emotional responses are possible. We come to see that "our way" of seeing things is perhaps just "one way" as opposed to "the way." Emotional intelligence then is the ability to navigate and consider the many possibilities and respond accordingly. Bohm made a similar point when he stated, "there is movement in that tacit knowledge, which is that it is exploring possibilities" (emphasis added) [1, p. 79], constantly 
"accommodating" our thinking to the world around us.

In her New York Times article "To Help Students Learn, Engage the Emotions" Jessica Lahey quotes Dr. Immordino-Yang: "It is neurologically impossible to think deeply about things you don't care about... When students are emotionally engaged, we see activations all around the cortex, in regions involved in cognition, memory and meaning-making, and even all the way down into the brain stem" [4]. Meaningful learning happens when teachers create an emotional connection to what might otherwise remain abstract concepts, ideas or skills and is marked by deep mastery and durable learning.

Emotionally, children are flexible thinkers and don't feel the need quite as adults do to defend their position and find the best arguments to do so. They are more curious and their thinking can travel in all directions, not just the ones they have staked out for themselves. The concepts they have of the world around them are attached to their imagination and not fixed ideas. Their imagination loves to travel. Imagination is curious, not defensive.

In The Atlantic, Andrew Simmons wrote an article "Literature's Emotional Lessons" - grappling with the way books make students feel not just analytical skills - should be part of the high-school English curriculum. If we want to focus on developing good decision-making skills, we cannot do so in a vacuum. Decision-making skills involve skills related to knowing how to act in real life situations. To make these decisions intelligently, we need to develop the children's awareness of their entire thinking process. Simmons also makes the following point: "In my experience teaching and observing other teachers, students spend a lot of time learning academic skills and rarely talk about emotional reactions they have to what they read - even when stories, as they often do, address dark themes" [6].

Dr. Jana Mohr-Lone, Founder of the Philosophy Learning and Teaching Organization (PLATO) at the University of Washington, in Seattle, responded to a question from Chris Weller in "Schools aren't teaching the most important subject for kids" in Business Insider by stating the following: "Occasionally, l'll have parents say to me 'You know, I think it might be too early for my kid to be thinking about racial identity,' ... And I always say 'Well, your kid must be white,' because if you grew up as a child of color, by the time you're seven or eight years old nobody needs to teach you about racial identity. You're already thinking about it" [8]. To help students cope with real life, unpleasant and disturbing portions of reality have to be included in classroom discussions on a personal, political, or societal level. I have had occasions where a child would cry during one of our philosophical discussion groups and friends would rally around her to comfort and console her. The teacher and I deliberately chose not to intervene to make the child "feel better." It is important that the child knows she is safe and it is safe to cry. Crying is not a negative experience. It is not a happy one, but not a negative one. Adults tend to make it such.

When children are given the space to experience their feelings in deeply moving ways, they are given the opportunity to get in touch with them and deal with them in constructive ways, thereby also learning about who they are. Children are resilient and eager to learn about the world they live in. How else will they learn to navigate a world of hope and dreams (I want to be a scientist when I grow up) but replete of injustice, strife and hardship as well. How can we educate students to be more conscientious citizens, when we discuss serious topics only from a "safe" and superficial standpoint as not to "rock the emotional boat."

To enable more connections to be made between both the limbic system and the neocortex, and to increase our ability for proprioception and awareness of thinking in the process of thinking, and how it affects our feelings and "metamood," Bohm suggests that we engage in what he calls "participatory thought," which in my view is precisely what doing philosophy with children does. "Participatory thought sees that everything partakes of everything. It sees that its own being partakes of the earth... literal thought tends to fragment, while participatory thought tends to bring things together" [1, p. 84]. Philosophy for and with children invites what Bohm calls "participatory thought." All are engaged in thinking together, "those implicit, tacit thoughts that are the foundation of consciousness are shared by all" [1, p. 93].

\section{"Incoherence" and Disassociated Thought}

If we only educate the abstract mind and not the thinking being, we become "incoherent" thinkers, as Bohm points out, disconnected from the world we live in, from other people, and from ourselves as well. This has dangerous consequences. Disassociated abstract thought can allow us to do the most horrible things to the environment, other life forms, and other people, and provide justifications for it. When abstract thought takes over, without the awareness of the tacit process of thinking, "incoherence" in thinking takes place and with it the problem of 'transference' of abstract thought to real life situations (as many teachers and university instructors are aware of). 
Incoherence in thinking is a result of what Bohm calls the paradox in thinking and feeling: "Thus, it is now more urgent than ever that we give attention ... to the inward dullness and nonperceptiveness which allows us to go on failing to notice the paradox in thinking and feeling... A mind caught in such paradox will inevitably fall into self-deception, aimed at the creation of illusions that appear to relieve the pain resulting from the attempt to go on with self-contradiction" [1, p. 66-67]. "In essence, therefore, what is needed is to go on with life in its wholeness and entirety, but with sustained, serious, careful attention to the fact that the mind, through centuries of conditioning, tends, for the most part, to be caught in paradoxes, and to mistake the resulting difficulties for problems" (emphasis added) [1, p. 68].

Bohm contends that thought creates feelings. "Well, I had the impulse to think. I thought something, and then came the feeling. It was caused in that way, and therefore that is all it means." But if you get the feeling that it does not come from thought, then it will tacitly be taken to mean a direct perception of reality" (emphasis added) [1, p. 81]. "Well, I have deep gut feelings about this, which must really be valid." That's a failure of proprioception in thought [1, p. 80].

Let's use racism or any kind of 'ism' as an example. Whether or not I am aware of my thinking less of someone because of their race, ethnicity, gender, etc., my tacit thought will generate feelings of fear, anger, contempt, etc. These feelings, then, in turn, generate a sense that these feelings are valid and therefore also true. In Bohm's words: "[they are] taken to mean a direct perception of reality." "But thought doesn't treat itself as a movement. It treats itself as truth - as just being there, telling you the way things are" [1, p. 81]. In other words, selfdeception creeps in when thoughts that generate certain feelings are conceived of as a direct perception of reality and therefore as true. Since these feelings are considered true, my reactions to these valid feelings are therefore justified. This is a perfect example of circular thinking.

Self-deception, then, comes from believing these self-generated "truths" are actually the "way things are" and there is no need to selfreflect or even question oneself. This explains why so little has changed regarding racism or sexism, even though we have come to grips with much of it, yet strictly on the level of abstract thought.

Throughout history, shifts brought about by historical events such as the civil war, the civil rights movement and women's suffrage, do affect the tacit, concrete process of thought. But change comes slowly, painstakingly, and incurs much sacrifice. It is indeed a failure of proprioception, if we are not aware of the "truths" we create.

In order to deal with this incoherence in thinking - Bohm suggests, that perceptiveness or proprioception can help us to "see" both thoughts simultaneously, meaning while operating from our assumptions, we are aware of them as well. "There is, however, some selfreference built into the whole system. There is what is called proprioception, or "self-perception... Thought lacks proprioception, and we have got to learn, somehow, to observe thought. In the case of the body, you can tell that somehow observation is taking place even when there is no sense of a distinct observer [1, p. 75-76].

Through proprioception, a space is created for thinking to move again, instead of being stuck in the non-moving thought/assumption, simply reacting to its triggers. Proprioception of thought liberates our thinking from the reflexes of thinking - the reflexes we have been educated (conditioned) into believing to be truths about the world we live in.

Reflexes of thought get in the way of thinking! Bohm states that when we treat thought as truth rather than as a movement we get stuck in the "truths," which obstruct the movement of thinking. In doing philosophy with children, we concentrate on thinking as a movement, thereby developing the child's capacity for coherent living, where thoughts, feelings and actions cohere.

\section{The Iceberg and the Entire Mind}

To me, explaining the world we live in abstract, rational terms, resembles the tip of the iceberg, whereas what we understand but cannot explain the same way exists below the surface. To describe what exists below the surface we use metaphors, analogies, poetry, music or scientific explanations such as space-time or the Higgs boson.

What is below is certainly as real as what exists above the surface. To believe that it is not as real has led to many catastrophic crashes throughout history. Abstract thought does not have the capacity for movement. And while we can engage in thought experiments and develop good reasoning and meta-cognitive skills, it lacks the ability for movement and therefore also the ability for proprioception of thought in action.

And since abstract thought does not originate within the living self it can never become aware of itself in the way that the tacit, concrete process of thought can. Awareness involves one's entire being which includes emotional awareness. This is also why abstract thought 
alone fails to transfer to real life lived experiences in life. It lacks the basis for transference, because it does not exist in lived relationship to reality. Abstract thought builds on what is known, whereas the tacit, concrete process of thought builds on what is not known... as does philosophy. Learning how to ride a bike involves riding it while not knowing how. We develop the ability to ride a bike in the process of riding it. Likewise, we can develop proprioception and awareness of thinking in the process of thinking.

Too much of our thinking (and philosophical thinking) takes place on the level of abstract thought, and this is where we go wrong and where we end up living a life that's "incoherent." It is out of sync. And while we think we can "impose" abstract thought to establish coherent functioning, there is nothing further from the truth. It only leads to further incoherent living, which furthers layers of self-deception and miscommunication.

Hanging banners in the classroom stating we need to respect each other, or be kind to each other can surely help as reminders, but cannot do the job of showing respect or kindness. This has to come from knowing what respect and kindness is at a tacit, concrete level and a deep emotional level. It has to come from a place of awareness.

In doing philosophy with children at a young age, we enhance children's awareness of their thinking, feeling, i.e. entire being. When children are encouraged to think with their entire being over the course of their education, functioning on a "coherent" level is enhanced. To be ecologically minded will mean to start acting ecologically as well.

1. Bohm D. (1996) On Dialogue. New York, Routledge [in Eng].

2. Elders L. (2011) HR Matters Magazine, iss. 15, July [in Eng].

3. Gibbs N. (1995) Time, vol. 146, no. 14, Oct. [in Eng].

4. Lahey J. (2016) The New York Times, May 4 [in Eng].

5. Meninger K. (1942). Love Against Hate. New York, A Harvest Book, Harcourt, Brace \& World, Inc. [in Eng].

6. Simmons, A. (2015) The Atlantic, Apr. 5 [in Eng].

7. The Collected Dialogues of Plato (1962).

New Jersey, Princeton University Press [in Eng].

8. Weller Ch. (2016) Business Insider, Aug. 27 [in Eng].

9. Zelevansky, N. (2019) The New York Times, Nov. 20 [in Eng].
Для цитирования: Тиллманнс М.

Как философствование с детьми

способствует развитию проприоцепции мышления и эмоционального интеллекта // Социум и власть. 2020. № 1 (81). С. 90-95. DOI: 10.22394/1996-0522-2020-1-90-95.

DOI: 10.22394/1996-0522-2020-1-90-95

УДК $101.8+101.9$

\section{КАК ФИЛОСОФСТВОВАНИЕ} С ДЕТЬМИ СПОСОБСТВУЕТ РАЗВИТИЮ ПРОПРИОЦЕПЦИИ МЫШЛЕНИЯ

\section{И ЭМОЦИОНАЛЬНОГО} ИНТЕЛЛЕКТА

\section{Тиллманнс Мария да Венза (Tillmanns Maria daVenza),}

доктор философии, Калифорнийский университет (Сан-Диего, США)

UC San Diego 9500 Gilman Dr. La Jolla, CA 92093

E-mail: davenza@sbcglobal.net

\section{Аннотация}

Статья представляет собой более подробное рассмотрение тех проблем, которые были намечены в первой части данного исследования «Применение проприоцепции мышления в философствовании с детьми» («Социум и власть», 2019, № 4). На этот раз автор уделяет внимание характеристике мышления как процесса в практике философствования с детьми, обосновывая эффективность данной практики, которая формирует осознанность действий и развивает эмоциональный интеллект. Автор противопоставляет статичное абстрактное мышление динамике неявного конкретного мыслительного процесса. Философствование с детьми в диалоговой форме всецело вовлекает в мыслительный процесс, фокусируется на самом мышлении, которое постоянно развивается с учетом разных точек зрения, усложняется и на эмоциональном уровне углубляет понимание.

\section{Ключевые понятия:}

философия с детьми,

проприоцепция,

чувственное и рациональное,

абстрактное мышление vs неявный конкретный мыслительный процесс,

эмоциональный интеллект. 